\title{
The Effect of Knowledge Taxpayer, Moral Taypayer and Tax Sanctions on Taxpayers Compulsory
}

\author{
Dyah Purnamasari and Yoyo Sudaryo
}

\begin{abstract}
This research examine the relationship between knowledge taxpayer, moral taxpayer, tax sanctions, taxpayers Compulsory. Objects in this study are Taxpayer Knowledge, Taxpayer Moral, Tax Sanctions, and Taxpayer Compliance. This research was conducted at KPP Pratama Bandung. Therefore the authors use population data from taxpayers who are active in reporting taxes even though it may not be in every year. Sample determination technique used in this research is non probability sampling. Sampling is done by distributing questionnaires to taxpayers who are paying annual tax return. The sample in this study is taken from the population of Individual Taxpayers in the Tax Office Pratama Tegalega Bandung. The results of research in the field, can be known partially knowledge of taxpayers have a positive effect on taxpayer compliance of individuals in KPP Pratama Tegalega Bandung.
\end{abstract}

Index Terms-Knowledge taxpayer, moral taxpayer, tax sanctions, taxpayers compulsory.

\section{INTRODUCTION}

Tax is a contribution of the people to the State treasury under the Law with no reciprocal services (counter-achievements) that can be directly demonstrated and used to pay public expenditures. Taxes are defined as levies imposed by a State on behalf of its citizens under a law to which the State charges no direct contra- rate to its citizens [1]-[4]. Most of the taxpayers obtain tax knowledge from tax officials, but also obtained from television, radio, newspapers and others. However, the delivery of this tax knowledge is not often done. This lack of socialization raises the low awareness of the public that has an impact on the low level of taxpayer compliance in performing its tax obligations [5]. Knowledge is everything that is known to be obtained from the touch of the sensory panda to a particular object. Knowledge can basically be obtained through teaching and training efforts, as well as through education in both formal and non-formal education [6]. In relation to taxes, tax knowledge is a knowledge of the general concept of taxation, the type of tax applicable in Indonesia from tax subjects, tax objects, tax rates, tax calculations payable, tax records payable to how filling tax reporting. It can be concluded that the tax

Mauscript received August 23, 2018; revised October 12, 2018

Dyah Purnamasari is with Accounting Department, Widyatama University Bandung Indonesia \& Doctoral Students of Management Department, Faculty of Economics and Business, Pansudan University, Bandung, Indonesia (e-mail: Dyah.purnamasari@widyatama.ac.id).

Yoyo Sudaryo is with Sekolah Tinggi Ilmu Ekonomi Indonesia Membangun (STIE INABA), Bandung, Indonesia (e-mail: y.sudaryo@yahoo.co.id). knowledge is tax information that can be used by the taxpayer as the basis for acting, making decisions, and for taking a certain direction or strategy with respect to the implementation of the rights and obligations in the field of taxation [7].

Ref. [8] member of the study of the importance of tax knowledge for taxpayers greatly affect the attitude of the taxpayer to the taxation system of a State that is considered fair. With the increasing knowledge of taxation society through formal and non-formal taxation education will have a positive impact on the understanding and awareness of taxpayers in paying taxes. With intensive and continuous extension of taxation will improve the understanding of taxpayers about the obligation to pay taxes as a form of national mutual cooperation in the collection of funds for the benefit of government financing and national development. Tax phenomenon as the backbone of State revenue is an interesting phenomenon to be studied. On the one hand the State requires taxes as the largest source of revenue, on the other hand required a high volunteer of taxpayers to meet its tax obligations. It can be said that few people in each country willingly and without grumbling carry out their tax obligations. Even more taxpayers are trying to escape tax either by manipulating or minimizing the amount of taxes to be paid.

Taxpayer compliance is strongly influenced by the morality of the taxpayer. This is because paying taxes is an activity that can't be separated from the condition of the taxpayer's behavior itself. The moral aspect in the field of taxation concerns two things: (1) the moral obligation of the taxpayer in carrying out his tax obligations as a good citizen and (2) concerning the taxpayer's moral awareness of the tax revenue allocation by the government. The study has found empirical evidence of a significant relationship between taxpayer morality and taxpayer compliance [9]. Taxpayers who have a good moral conscience as citizens in performing their tax obligations are different from citizens who have no moral awareness. Thus expected by the morality aspect of the taxpayer will increase the tendency of the taxpayer in fulfilling his tax obligations. If the Taxpayer feels that the tax court has been applied to all taxpayers by not distinguishing the treatment between corporate taxpayers with individuals, large taxpayers with small taxpayers in the sense that all taxpayers are treated fairly then any taxpayer is likely to run its tax obligations with good or in other words leads to compliance in the taxpayer [11].

Tax compliance is the act of the taxpayer in fulfilling his tax obligation in accordance with the provisions of the applicable laws and regulations of taxation in a country (Minister of Finance No.544 / KMK.04 / 2000). The taxpayer 
compliance criteria itself is timely in submitting SPT, having no tax arrears, organizing bookkeeping and never being sentenced for committing criminal offenses in the field of taxation. To meet these criteria, preventive measures are required for taxpayers to pay and report on time tax returns. An effective way for taxpayers to become obedient taxpayers is to apply sanctions indiscriminately and be implemented consequently. Understanding Sanction tax itself is: "Taxation sanctions are a guarantee that the provisions of tax laws and regulations will be obeyed/obeyed/obeyed. Or it could be in other words tax sanction is a preventive tool (preventive) for Taxpayers do not violate the norms of taxation [1]-[4].

In essence, the imposition of tax sanctions imposed to create compliance in carrying out its tax obligations. Therefore, it is important for taxpayers to understand tax sanctions to know the legal consequences of what is done or not done. Sanctions are required to provide lessons for tax breakers. Thus, it is expected that the tax regulations are complied with by the taxpayers. Knowledge of sanctions in taxation is important because the Indonesian government chooses to implement Self Assessments System in the framework of tax collection. Under this system, the taxpayer is given the confidence to calculate, deposit and report his own tax. To be able to run it well, then every taxpayer requires tax knowledge, both in terms of regulations and technical administration. To increase tax payments, the Directorate General of taxes will not stop socializing the importance of paying taxes. In addition to persuasive action, it has prepared strict sanctions such as imposing penalties for late tax payments. Provision of sanctions is made to realize the target of tax revenue and increase the amount of taxpayer compliance, especially in the area of West Java.

Based on the above description, the success of a country's tax revenue depends on the government's efforts in improving compliance and suppressing tax manipulation. Some of the steps governments can undertake include creating a professional public service, managing tax money fairly and transparently, making tax laws easily understood by taxpayers and increasing law enforcement actions against non-compliant taxpayers. Based on the description above, the authors are interested to conduct research entitled "THE EFFECT OF KNOWLEDGE TAXPAYER, MORAL TAXPAYER AND TAX SANCTIONS ON TAXPAYERS COMPULSORY (Case study on KPP Pratama Bandung Tegalega)".

Based on the description of the above background, the authors identify several issues as follows:

1) How the influence of taxpayer's knowledge on taxpayer compliance.

2) How does the taxpayer's moral influence on taxpayer compliance.

3) How the effect of tax sanctions on taxpayer compliance.

4) How the influence of taxpayers' knowledge, taxpayer morale, and tax sanctions on taxpayer compliance.

\section{THEORETICAL FRAMEWORK}

Law No.16 Year 2009 on General Provisions and Tax Procedures there are three tax collection systems, namely:

1) Self-Appraisal System. Self Assessment System is a tax collection system that determines the amount of tax payable in accordance with the provisions of the tax law.

2) Official Rating System. The Official Rating System is a tax collection system, which the tax apparatus itself determines (excluding taxpayers) the amount of tax payable.

3) Withholding System. Withholding System is a tax collection system, which is calculated by the taxpayer by a third party. One type of collection system that is applied in Indonesia is Self Assessment System. This collection system will work well if the community has high knowledge and discipline. Knowledge of tax is tax information that Taxpayer can use as basis for acting, making decision, and to blowing certain direction or strategy with execution of its right and obligation in the field of taxation [7].

The concept of knowledge or understanding of taxes, namely:

1) Knowledge of General Provisions and Tax Procedures;

2) Knowledge of Indonesia's Taxation System;

3) Knowledge of Taxation Functions.

According to the Great Dictionary of Indonesia, consciousness is the state of knowing, the state of understanding and feeling voluntarily. This sense is also an awareness of one's self as well as the group. So Taxpayer awareness is the attitude of understand Taxpayer to understand the meaning, function and willingness to pay taxes voluntarily, awareness Taxpayer is the most important factor in the tax system. Knowledge of tax and awareness will influence attitudes of taxpayers to tax obligations, the higher the knowledge and awareness of Taxpayers of the tax regulations, the higher the taxpayer compliance value. Taxpayer Compliance is a Taxpayer's action in fulfilling its tax obligations in accordance with the provisions of applicable laws and regulations on taxation in a country. Compliance fulfilling voluntary tax obligations is the backbone of the self assessment system, whereby the Taxpayer is responsible for establishing his own tax obligations and then timely paying and reporting the tax.

There are two kinds of compliance that is:

1) Material Compliance. A situation where the Taxpayer substantive/essence meets all the provisions of taxation material, namely according to the content and the soul of the tax law.

2) Formal Compliance. A State in which the Taxpayer meets the tax obligations formally in accordance with the provisions of the tax law.

\section{1) Effect of taxpayer knowledge on taxpayer compliance}

There is a significant influence between taxation knowledge on taxpayer compliance level. The better the Taxpayer's knowledge of taxation, the higher the taxpayer compliance rate. The compliance of Taxpayers in carrying out their tax obligations is influenced by the level of education and taxpayers' knowledge of the tax itself.

\section{2) The moral impact of taxpayers on taxpayer compliance}

Theory of moral reasoning can be used to explain the influence of the taxpayer's moral to taxpayer compliance. This theory states that moral decisions can be influenced by tax sanctions on the low level of reasoning morale, peer 
expectation at moderate levels, and fairness issues at the highest level [11]. More taxpayers using the moral principle in tax payment decisions will be more compliant than other taxpayers.

\section{3) Effect of tax sanctions on taxpayer compliance}

The feeling of fear of being caught and imprisoned due to tax smuggling is a deterrent to reducing tax smuggling. If there is a feeling of no mistake in relation to the implementation of the provisions of the tax law has developed among the taxpayers, this means that the road to compliance and awareness to meet the obligations of taxation. Taxpayer Compliance Influenced Taxpayer Knowledge, Taxpayer Moral, and Tax Sanctions. The existence of several theories related to taxpayer compliance. The following will be explained each:

\section{a) Prospect theory}

Prospect theory is one of the theories related to taxpayer compliance. This theory explains how decisions are dramatically influenced by the means or constraints encountered. These limits are important for decision-making because of three things: (1) whether expenditure is described as an uncompensated loss or as a cost, (2) whether the reference level is determined by the specific matters in which the decision was made, more comprehensive, such as total assets or total annual costs, and (3) whether the main point is profit or loss.

\section{b) Deterrence Theory}

Deterrence Theory is one of the theories associated with taxpayer compliance. This theory is based on the benefit paradigm. This theory illustrates a model that takes into account the potential costs and benefits to be derived from a chosen action. Legal sanctions are potential losses arising from illegal acts that have been committed. A person's perception of legal certainty will affect his commitment to illegal acts. Someone will try to avoid any kind of potential loss due to the action of breaking the rules.

\section{c) Cognitive Structures}

The assumption that was not established in previous research, that attitudes toward tax affect the behavior of taxpayers through intentions and intentions ultimately affect the behavior of paying taxes. Theory of Reasoned Action identify three main aspects of attitude-behavioral relationships. First, which is related to the parallelism between attitudes and behavior, where there is a strong relationship between attitude and behavior. This is derived from a strong relationship between the target element and the action of the attitude and behavior. Second, with regard to attitudes as behavioral drivers, then attitudes will affect actions as opposed to attitudes affecting objects. Third, the whole of the behavioral criterion is a factor.

\section{d) Agency Theory}

Agency theory is concerned with situations where an individual works as an agent for another individual (principle) and delivers results to his or her principle. Although analysis of the relationship between agent-principle is mostly related to the relationship between management-owner and labor-management, but the application associated with income tax can illustrate the relationship between tax preparers, tax payers, and the government [10].

Based on the above description, the framework of this research can described as follows:

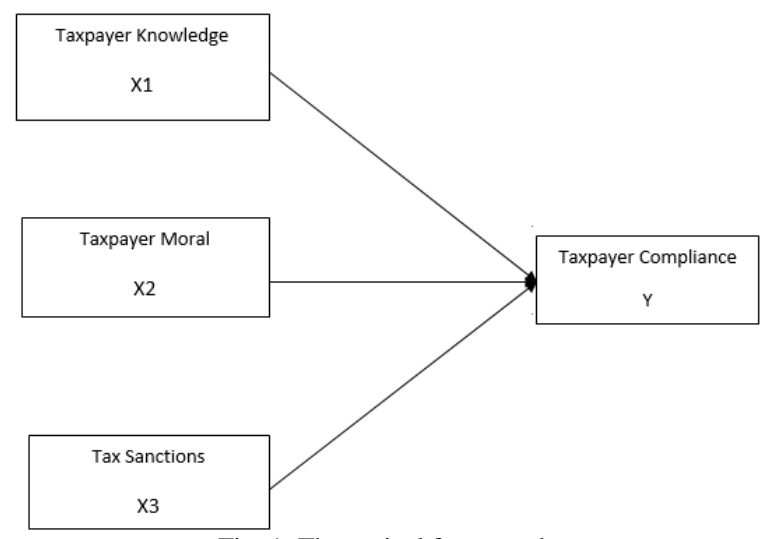

Fig. 1. Theoretical framework.

\section{Research Methodology}

Objects in this study are Taxpayer Knowledge, Taxpayer Moral, Tax Sanctions, and Taxpayer Compliance. This research was conducted at KPP Pratama Bandung. Referring to the purpose of research conducted is To know the influence of Taxpayer Knowledge, Taxpayer Moral, and Tax Sanctions against taxpayer compliance. Population in this study are all registered private taxpayers and must report annual tax returns to KPP Tegalega Bandung. However, this amount does not show all Taxpayers who actively pay taxes. Many taxpayers are registered with KPP Tegalega who own NPWP but do not pay taxes actively. Therefore the authors use population data from taxpayers who are active in reporting taxes even though it may not be in every year. Sample determination technique used in this research is non probability sampling. Sampling is done by distributing questionnaires to Taxpayers who are paying annual tax return. The sample in this study is taken from the population of Individual Taxpayers in the Tax Office Pratama Tegalega Bandung reporting the SPT of 35,704 people (end of 2016).

Taking into account the limited time available, the authors set the maximum number of samples of at least 100 questionnaires to be disseminated and calculations will be processed using SPSS 24. The sample criteria in this study are:

1) Personal Person who carries on business or free employment;

2) An individual who does not run a business or a free employment, earning income above Taxable Income (PTKP) must register by no later than the end of the following month;

3) Married Women who are taxed separately, because they live separately on the basis of a judge's decision or are required in writing based on the separation of income and property agreement;

4) Individual Taxpayer of a Certain Entrepreneur who owns a place of business different from residence.

\section{RESULTS AND DISCUSSIONS}

Effect Analysis of Taxpayer Knowledge, Taxpayer Moral 
and Tax Sanction to Taxpayer Compliance (Case Study at KPP Pratama Bandung Tegalega). Analyze the influence of taxpayers' knowledge, taxpayer morale and tax sanctions on taxpayer compliance, will be analyzed using multiple linear regression. Terms in the regression analysis of independent variables and dependent variables are required to have the scale of measurement of interval/ratio data. Since the data scale used is assumed to be ordinal, the data transformation must be transformed into intervals using the SPSS 24.0 program.

\section{A. Effect of Taxpayer Knowledge on Personal Taxpayer Compliance}

The hypothesis that taxpayers' knowledge positively affects individual taxpayer compliance has been proven through testing. Through t-test obtained the result that hypothesis stating the knowledge of taxpayers do not significantly affect the taxpayer compliance person (Ho) rejected. This means that the knowledge of taxpayers in KPP Pratama Tegalega Bandung can improve taxpayer compliance person. Based on the results of research taxpayers have a positive and significant impact on taxpayer compliance of individuals with the contribution of the given effect of $15 \%$.

1) Taxpayers' knowledge of the tax function greatly affects the taxpayer's liability rate of the individual in paying the tax, therefore the taxpayer of the individual must know how the tax functions, tax regulations, registration as an individual taxpayer, the procedure of paying taxes and knowing tax rates.

2) Taxpayer's knowledge of tax regulations, meaning that the more knowledge a person's taxation, then the higher compliance will be better.

3) Taxpayer Knowledge on the way of registration as a taxpayer, meaning that someone who has worked and have salary above PTKP already should have NPWP.

4) Taxpayer's Knowledge on the procedure of payment of tax, meaning that the taxpayer must know the tax payment procedure is good and right.

5) Taxpayer Knowledge of tax tarif, meaning taxpayer must know the amount of tax tariff applicable in Indonesia.

\section{B. The Moral Impact of Taxpayers on the Compliance of Individual Taxpayers}

The hypothesis stating that the taxpayer morality has a positive effect on the compliance of individual taxpayers has been proven through testing. Through t-test results obtained that the hypothesis that states the taxpayer morale has no significant effect on individual taxpayers (Ho) rejected. This means that taxpayer morale in KPP Pratama Bandung Tegalega can improve taxpayer compliance of individuals. Based on the results of taxpayer moral studies have a positive and significant impact on compliance obligatory of individuals with the contribution of the given effect of $4.3 \%$.

In this study, the taxpayer's morality in KPP Pratama Bandung Tegalega was the respondent included in the good category, in the sense that the taxpayer person who is registered and obliged to report the Annual Tax Return to KPP Pratama Bandung Tegalega have good morals to comply with tax regulations. But the percentage is still low and if seen from each indicator put forward, there are some indicators indicate the morale of taxpayers that have not good to tax compliance include, taxpayers feel non-compliance tax is an act that does not violate ethics, taxpayers do not feel guilty when doing non-tax compliance, and the taxpayer declares noncompliance tax is a non-infringing act in his life. From these indicators can be concluded that the level of compliance is still low one of them caused by the moral taxpayers who have not very good to obey the tax laws.

The results of this study support the theory put on [12] which states that taxpayer morale is an intrinsic motivation to pay taxes arising from the moral obligation to pay taxes or trust in contributing to public provision. The moral aspect in the field of taxation concerns two things, namely (1) the obligation of taxation is a moral obligation that must be fulfilled by every taxpayer, and (2) concerning moral awareness related to the allocation or distribution of tax revenue. Taxpayers who have a good moral conscience as citizens in performing their tax obligations are different from citizens who have no moral awareness. Thus expected by the morality aspect of the taxpayer will increase the tendency of the taxpayer in fulfilling his tax obligations.

\section{The Effect of Tax Sanctions on Personal Taxpayer Compliance}

In testing the hypothesis can be seen tcount and t_table shows the value of $8.174>1.661$. If the value of $t$ _count> t_table, then Ho rejected and Ha accepted, it means that partially the application of tax sanctions have a positive effect on taxpayer compliance of individuals at the Tax Office Pratama Bandung Tegalega. The sanctions provided must be clear in order for an Individual Taxperson to know how the rules and sanctions can create a deterrent effect to an individual Taxpayer if committing a tax violation. The sanctions provided do not recognize compromise, meaning that all aspects of society should be subject to the same sanctions in the absence of differences. Sanctions are given a balanced, meaning that if the taxpayer does not pay taxes then the sanction should be clear or not burdensome taxpayers. The sanction must give a deterrent effect, meaning that if the taxpayer violates the taxation provision, the sanction must be appropriate so that the taxpayer does not infringe the tax.

\section{Influence of Taxpayer Knowledge, Taxpayer Moral, and Tax Sanction to Personal Taxpayer Compliance}

Hypothesis which states that the knowledge of taxpayers, taxpayer morale, and tax system have a positive effect on the taxpayer compliance of individuals has been proven through testing. Through the F-test with 5\% error rate, the results obtained that the hypothesis that states the taxpayer's knowledge, taxpayer morale, and tax system do not affect the taxpayer person (Ho) rejected. This means that the influence of taxpayer's knowledge, taxpayer's morale, and the existing tax system felt by the taxpayer affects the compliance level in KPP Pratama Bandung Tegalega. The amount of simultaneous influence of taxpayers' knowledge, taxpayer morale, and tax sanction on personal taxpayer compliance level in KPP Pratama Tegalega Bandung is 64.7\%.

The results of this study also support the statement put on taxpayer compliance is defined as entering and reporting 
timely information required, correctly filling in the amount of tax payable and paying the time tax without coercive action. The level of compliance is influenced by several factors, namely the condition of tax administration system of a State, service to the taxpayer, tax law enforcement, tax audit and tax tariff. Awareness and compliance with tax obligations also depends on the willingness of the taxpayer, to what extent the taxpayer will comply with the provisions of the law. In the case of taxation the intended taxpayer dutifully defines the meaning and criteria. The taxpayer is delivering (paying and reporting) SPT on time and also SPT delivered true writing and calculation as well as complete documents required. Therefore, as owed in Regulation of the Minister of Finance of the Republic of Indonesia Number 192/PMK. 03/2007, in principle tax compliance is the action of the Taxpayer in the fulfillment of tax obligations in accordance with the provisions of the laws and regulations applicable taxation laws in force in a State.

\section{CONCLUSION AND SUGGESTIONS}

Based on the results of research on the influence of tax mandatory knowledge, taxpayer morale and tax sanctions on compulsory compliance, the following conclusions can be drawn:

1) Based on the results of research in the field and based on the results of processing, can be known partially knowledge of taxpayers have a positive effect on taxpayer compliance of individuals in KPP Pratama Bandung Tegalega, meaning that if the taxpayer knowledge increases then taxpayer compliance will increase.

2) Based on the results of research in the field and is based on the results of processing, can be known in partial moral compulsory taxpayers have a positive effect on taxpayer compliance of individuals in KPP Pratama Bandung Tegalega, meaning that if the taxpayer morally to obey the existing tax regulations increased then compliance taxpayers will increase.

3) Based on the results of research in the field and based on the results of processing, can be known partially sanctioned taxation have a positive effect on taxpayer compliance of individuals in KPP Pratama Bandung Tegalega, it's mean if sanctions tax enforced then taxpayer compliance will increase.

4) Based on the results of research in the field and is based on the results of processing, can know the knowledge taxpayers, taxpayer morale, and sanctions taxation simultaneously have a positive effect on taxpayer compliance of individuals in KPP Pratama Tegalega Bandung, meaning taxpayer knowledge, and tax sanctions may significantly affect the taxpayer's personal compliance.

\section{SUGGESTIONS}

Based on the results of research, the authors suggested suggestions that are expected to be useful input for the parties concerned as follows:

1) Directorate General of Taxation

a) Taxpayer Knowledge. Self Assessment System, giving taxpayers trust to register, calculate, pay and report their own tax obligations. With this system, taxpayers are required to study the procedure of registration, taxation regulations and tax calculation, therefore the role of KPP and DGT is very necessary in the conduct of socialization and counseling about the procedure of registration, taxation regulations and tax calculation payable. If the taxpayer's knowledge of tax regulations is higher, it will increase taxpayer compliance that will affect the state revenue from the tax sector.

b) Taxpayer Moral. Trust also affects the morals of taxpayers, with the motivation to pay taxes arising, one of them in the form of optimal socialization of taxes to the community. This will affect the community by paying taxes on a voluntary basis.

c) Tax Sanctions. Variables Sanction taxation is the variable that most contribute in improving taxpayer compliance, therefore the tax institution in this case the Directorate General of Taxes and Tax Office Pratama Tegalega Bandung better give special attention in this regard.

2) Tax Service Office. In completing the administration of KPP should increase the counters to facilitate the process of tax payments. In addition, employees should be given quality work training to provide better service to taxpayers.

3) Future Researcher. Research conducted by the authors is limited to the knowledge of taxpayers, taxpayer morale, and tax sanctions. Researchers do not investigate further about other factors that can improve taxpayer compliance, therefore expected further research can further examine other factors that can improve taxpayer compliance.

\section{ACKNOWLEDGMENT}

The authors are grateful to the anonymous reviewers for their comments on earlier version of this article. The authors wish to thank Widyatama University, Bandung, Indonesia, and special thanks to Dr. Meiryani, Binus University, Jakarta, Indonesia.

\section{REFERENCES}

[1] D. Esy, 2012, "Factors affecting the use of e-filling facilities by taxpayers as means of online and realtime delivery of SPT," Thesis, Semarang: Diponegoro University, April 2017.

[2] C. S. Troutman, "Moral comment to tax compliance as measured by the development of moral reasoning and attitudes to wars the fairness of the tax laws," Dissertation, Oklahoma State University, USA, 1993

[3] H. A. Asri, The New Paradigm of Indonesian Taxation: Political Economy Perspective, Integrita Dynamics, 2004.

[4] B. Witono, "The role of tax knowledge in taxpayer compliance," Journal of Accounting and Finance, vol. 7, no. 2, pp. 196-208, 2008.

[5] H. N. Sentosa, "The environmental and tax moral effect on taxpayer attitude and compliance at Starred Hotel in Bali Province," Dissertation, Airlangga University: Surabaya, 2006.

[6] K. R. Salman and M. Farid, "The influence of tax attitude and morale on taxpayer compliance in banking industry in Surabaya," Thesis, Surabaya: STIE Perbanas, 2009

[7] A. Icek, Organizational Behavior and Human Decision Processes, University of Massachusetts Amherst, USA, 1991.

[8] N. Cahyonowati, "Tax moral and compliance model: individual taxpayer," JAAI, vol. 15, no. 2, pp. 161-177, 2011.

[9] J. A. Nugroho, "Influence of Taxpayer Attitude on Implementation of Fine Sanction, Fiscal Service and Tax Awareness to Taxpayer Compliance," Thesis, Semarang: Diponegoro University Postgraduate Program, 2006.

[10] Waluyo, "Indonesian Taxation", Jakarta: Salemba Empat, 2011. 
[11] Dyah Purnamasari, "The Effect of Changes in Return on Asset, Return on equity and Economic Value Added to The Stock Price Changes and Its Impact on Earnings per Share," Research Jouurnal Of Finance and Accounting, 6/6/2015

[12] Dyah Purnamasari and Yoyo Sudaryo, "Strategy Development Micro Small and Medium Business Performance in Small and Medium Enterprises (SMES) Cibaduyut Shoe Bandung, "International Journal of Scientific and Technology Research, 6/3/2017.

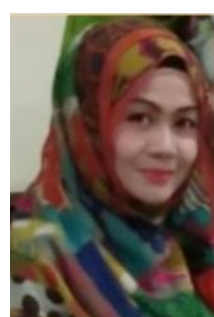

Dyah Purnamasari obtained her master degree in accounting with a concentration in taxation from Padjadjaran University. Dyah Purnamasari is a student of Management Department, Faculty of Economics and Business, Pansudan University, Bandung, Indonesia. She worked as a lecturer at Widyatama University. Her research interests include taxation, financial reporting and financial accounting. 